https://doi.org/10.52058/2786-4952-2022-2(7)-853-863

Дрозд Лідія Вікторівна кандидат психологічних наук, викладач кафедри спеціальної освіти, Херсонський державний університет, вул. Університетська, 27, м. Херсон, 73000, тел.: (099) 255-69-23, https://orcid.org/0000-0001-5406-2942

Пшенична Наталя Сергіївна доцент, Бердянський державний педагогічний університет, вул. Шмідта, 4, м. Бердянськ, 71100, тел.: (099) 624-56-27, https://orcid.org/0000-0002-0351-4950

Ляска Оксана Петрівна кандидат психологічних наук, доцент, Заклад вищої освіти «Подільський державний університет», м. Кам'янець-Подільський, 32316, вул. Шевченка, 13, тел.: (067) 912-13-39

\title{
ІНКЛЮЗИВНА ОСВІТА: РЕАЛІЇ СЬОГОДЕННЯ ТА ПЕРСПЕКТИВИ РОЗВИТКУ
}

Анотація. У статті встановлено актуальність вивчення стану системи інклюзивної освіти в Україні, зокрема підкреслено, що гуманізація освітньої системи, забезпечення інтеграції дітей 3 особливими потребами в загальноосвітній простір є одним із пріоритетів сучасної державної політики. Доведено актуальність та доцільність дослідження проблеми готовності навчати та особливостей підготовки асистента до професійної діяльності за умов інклюзії. Вивчено особливості формулювання терміну «інклюзія» 3 точки зору різних авторів та висвітлено основні ідеї концепції інклюзивної освіти в зарубіжних та вітчизняних наукових працях. Проведено аналіз стану інклюзивної освіти в Україні. Визначено ряд факторів, які гальмують становлення та розвиток інклюзивної освіти. Сформульовано низку взаємопов'язаних організаційних важелів, що спрямовані на активізацію розвитку інклюзивної освіти в Україні. Висвітлено досягнення в галузі інклюзивної освіти в Україні, зокрема, створення достатньої матеріальної бази в спеціальних навчальних закладах, які забезпечують належні умови для надання допомоги дітям від 2 до 18 років, що отримують дошкільну та загальноосвітню середню освіту на умовах інклюзії, прослідковано тенденцію змін динаміки кількості учнів, навчальних закладів, класів та асистентів, що дозволило забезпечити стрімкий розвиток інклюзивної освіти у 2015-2020 роках. Наголошується, що аналіз інклюзивної освіти в Україні свідчить про збільшення кількості дітей 3 особливими освітніми потребами, які відвідують загальноосвітні школи з метою соціалізації, навчання, виховання та розвитку на благо суспільства. При цьому в дослідженні висвітлюються суттєві недоліки сучасної системи інклюзивної освіти, зокрема підкреслюється, що надзвичайно 
гострою є проблема підготовки кадрів в даній сфері, оскільки вимоги до рівня компетентності вчителя-дефектолога та асистента вчителя $є$ високими, і питання забезпечення належного рівня освіти даних категорій працівників потребують додаткової уваги.

Ключові слова: інклюзивна освіта, особливі освітні потреби, соціальна інклюзія, інклюзивне освітнє середовище, асистент вчителя, інклюзивні класи.

Drozd Lydia Viktorivna $\mathrm{PhD}$ in Psychology, Lecturer at the Department of Special Education, Kherson State University, Universytetska St., 27, Kherson, 73000, tel.: (099) 255-69-23, https://orcid.org/0000-0001-5406-2942

Pshenichna Natalia Serhiivna Associate Professor, Berdyansk State Pedagogical University, Schmidt St., 4, Berdyansk, 71100, tel.: (099) 624-56-27, https://orcid.org/0000-0002-0351-4950

Liaska Oksana Petrivna $\mathrm{PhD}$ in Psychology, Associate Professor, Higher educational institution "Podillia State University", Shevchenko St., 13, Kamianets-Podilskyi, 32316, tel.: (067) 912-13-39

\section{INCLUSIVE EDUCATION: CURRENT REALITIES AND PROSPECTS FOR DEVELOPMENT}

Abstract. The article establishes the relevance of studying the state of inclusive education in Ukraine, in particular, emphasizes that the humanization of the education system, ensuring the integration of children with special needs in the educational space is one of the priorities of modern public policy. The relevance and expediency of the study of the problem of readiness to teach and the peculiarities of the assistant's preparation for professional activity under the conditions of inclusion are proved. The peculiarities of the formulation of the term "inclusion" from the point of view of various authors are studied and the main ideas of the concept of inclusive education in foreign and domestic scientific works are highlighted. The analysis of the state of inclusive education in Ukraine is carried out. A number of factors that hinder the formation and development of inclusive education have been identified. A number of interconnected organizational levers aimed at intensifying the development of inclusive education in Ukraine have been formulated. The achievements in the field of inclusive education in Ukraine are highlighted, in particular, the creation of sufficient material base in special educational institutions that provide appropriate conditions for providing assistance to children from 2 to 18 years of age receiving preschool and general secondary education on inclusive terms. students, educational institutions, classes and assistants, which allowed to ensure the rapid development of inclusive education in 2015 2020. It is emphasized that the analysis of inclusive education in Ukraine shows an increase in the number of children with special educational needs who attend secondary schools for socialization, education, upbringing and 
development for the benefit of society. The study highlights the significant shortcomings of the modern system of inclusive education, in particular emphasizes that the problem of training in this area is extremely acute, as the requirements for the level of competence of special education teachers and teacher assistants are high. extra attention.

Keywords: inclusive education, special educational needs, social inclusion, inclusive educational environment, teacher's assistant, inclusive classes.

Постановка проблеми. Розвиток сучасного суспільства визначає повагу до людського різноманіття, встановлення принципів солідарності та безпеки, практичне втілення яких забезпечує захист та повну інтеграцію в суспільство всіх груп населення, особливо людей 3 обмеженими можливостями. Це пов'язано 3 визначенням головної мети суспільного розвитку - створення «суспільства для всіх». Основою такої інтеграції є концепція цілісного підходу, відкриття шляху до реалізації прав і можливостей для всіх, що передбачає забезпечення, як одного з найголовніших складових даного процесу, рівного доступу до якісної освіти [1].

За даними Всесвітньої організації охорони здоров'я, лише 20\% народжених дітей вважаються здоровими, інші або страждають на розумові та фізичні вади, або перебувають у стані між здоров'ям та хворобами. Довгий час основним закладом навчання дітей 3 різними захворюваннями вважалася спеціальна школа, орієнтована на виховання дітей зі специфічними недоліками. Проте перед дитиною, яка закінчила спеціальний заклад, постає проблема подальшого навчання, проблема пристосування до суспільства здорових людей [2].

Одним із пріоритетних напрямів сучасної державної політики є гуманізація системи освіти, що забезпечує інтеграцію дітей з особливими потребами в загальноосвітній простір. Важливими умовами $є$ визнання за такою дитиною прав, інтересів, потреб, підтримка в процесі соціалізації тощо. Тому набуває актуальності інклюзивна освіта, яка передбачає спільне проживання дітей 3 вадами психофізичного розвитку зі здоровими однолітками, створення рівних можливостей та забезпечення варіативності для дітей в отриманні якісної освіти відповідно до їх індивідуальних можливостей [3].

Актуальним залишається питання толерантності та суспільного сприйняття дітей з ООП у загальноосвітньому середовищі, специфічним і значущим $\epsilon$ питання фінансування всіх заходів та змін, що необхідно застосувати у рамках навчального закладу для успішного впровадження інклюзивної освіти. I не менш важливим є питання підготовки вчителів, що передбачений процесом впровадження інноваційних методів у навчальний план закладів освіти. Це, в тому числі, вимагає від вчителів вивчення практичного досвіду інших країн, що ініціюють програми стажування викладачів у університетах, фінансування яких має спрямовуватися на проекти інклюзивної освіти.

Аналіз останніх досліджень і публікацій. Термін «соціальна інклюзія» почав вживатися наприкінці 1980-х років. Соціальна інтеграція - це 
спрямований процес надання людям, яким загрожує бідність та соціальне відчуження, можливостей і ресурсів, необхідних для повноцінної участі в економічному, соціальному та культурному житті та досягнення рівня життя та процвітання, що відповідає високим стандартам якості. Держави, які діють відповідно до принципів соціальної інклюзії, повинні надавати людям більше можливостей для участі в підготовці та прийнятті рішень, які їх стосуються, а також у реалізації їхніх основних прав [4].

Більшість досліджень науковців були зосереджені на проблемах навчання, виховання та розвитку дітей 3 вадами психофізичного розвитку в загальноосвітній школі (М. Безруких, О. Гонєєв, С. Єфімова, Т. Ілляшенко, Г. Кумаріна, Н. Ліфінцева, В. Петров, Н. Стадненко, В. Тарасун, Н. Ялпаєва), також вивчалась побудова педагогічних моделей інклюзивного навчання дітей 3 різними типами онтогенезу (В. Бондар, В. Засенко, А. Колупаєва, І. Мамайчук, В. Назарина, Т. Сак, В. Синьов, В. Тарасун, О. Хохліна, С.Шевченко, Л. Шипіцина, Н. Шматко), підготовка педагогічних кадрів для роботи з дітьми в умовах інклюзивної освіти (А. Аніщук, О. Воробйова, Н. Кирста, О. Мартинчук, Т. П'яткрова, Г. Сіліна, С. Чупахіна).

У соціально-педагогічній науці цей термін 3'явився не так давно, вчені трактують його по-різному. Так, Л. Міщик вважає, що інклюзія - це процес підвищення ступеня участі всіх дітей у суспільному житті та різноманітних програмах.

А. Колупаєва трактує його як «єдину освітню систему, що забезпечує всім учням адекватну освіту, повне залучення дітей з особливими здібностями до різноманітних аспектів шкільної освіти, доступних іншим дітям».

Проте слід зазначити, що це визначення враховує лише педагогічний аспект. На думку Національної асамблеї людей з інвалідністю України, інклюзія - це процес, що забезпечує повноцінну участь усіх членів суспільства у всіх сферах життя. У цьому контексті ми вважаємо, що інклюзія - це комплексне поняття, яке включає соціальний та освітній компоненти. Соціальна інклюзія $є$ результатом переходу суспільства до нової концепції соціальної політики, заснованої на соціальній моделі інвалідності. Наслідками такого розвитку $\epsilon$ соціальна рівність, що дає змогу всім без винятку брати участь у суспільному житті на рівних правах і відчувати свою значущість.

Аналіз досліджень зарубіжних та вітчизняних наукових праць дає змогу виділити основні ідеї концепції інклюзивної освіти: 1) визнання рівних прав усіх здобувачів освіти і педагогів для одного суспільства; 2) підвищення ступеню участі учнів у навчально-виховному процесі та позакласній роботі при зниженні ступеня ізоляції частини учнів та студентів; 3) зміни політики, практики та культури навчального закладу 3 метою їх адаптації до різноманітних потреб здобувачів освіти, які навчаються в цьому навчальному закладі; 4) подолання бар'єрів на шляху якісної освіти та соціалізації всіх учнів, a не лише учнів 3 обмеженими можливостями та 3 пов'язаними 3 цим особливими освітніми потребами; 5) аналіз та вивчення спроб подолання 
перешкод у засвоєнні знань у загальноосвітніх навчальних закладах для окремих категорій учнів; 6) здійснення реформ i змін для покращення становища, соціального захисту всіх здобувачів освіти; 7) переконання, що відмінності між учнями є ресурсом, який сприяє педагогічному процесу, а не перешкодою, яку необхідно подолати; 8) визнання права дітей на освіту в загальноосвітніх навчальних закладах за місцем проживання; 9) покращення ситуації в школі загалом, як учнів, так і вчителів; 10) визнання ролі шкіл не лише у покращенні успішності учнів, а й у розвитку місцевих громад; 11) розвиток партнерських відносин між школами та місцевими громадами; 12) визнання того, що інклюзія в освіті $є$ одним із аспектів інклюзії в суспільстві.

Метою статті є визначення особливостей інклюзивної освіти в сучасному освітньому процесі та окреслення перспектив цієї сфери освіти, а також аналіз напрямів розвитку інклюзивної освіти в Україні.

Виклад основного матеріалу дослідження. Англійський термін «inclusion» означає «зберігати, включати, мати місце у своєму складі». Суть концепції інклюзї полягає в адаптації системи до потреб дитини. Йдеться про використання таких заходів, які дають змогу кожному брати участь у рівній мірі в академічному та громадському житті. Вперше інклюзія була схвалена Загальною декларацією прав людини 1948 року і знайшла своє відображення у всіх міжнародних документах у сфері освіти.

Інклюзивна освіта - це система освітніх послуг, заснована на принципі забезпечення фундаментального права дітей на освіту та права на освіту за місцем проживання, i включає навчання дітей 3 особливими освітніми потребами в загальноосвітніх навчальних закладах [3]. Це процес, у якому школа прагне задовольнити потреби всіх учнів, вносячи необхідні зміни в навчальний план і акумулюючи ресурси, щоб забезпечити рівні можливості для всіх дітей, незалежно від їх психофізичного стану.

«Інклюзивна освіта» - це комплексний процес забезпечення рівного доступу до якісної освіти дітей з особливими освітніми потребами шляхом організації їх навчання у загальноосвітніх навчальних закладах на основі особистісно-орієнтованих методів навчання 3 урахуванням індивідуальних особливостей цих дітей» (Концепція інклюзивної освіти) Постанова МОН від 01.10.2010 № 912).

За словами О. Коробкіної, «інклюзивна освіта - це система освітніх послуг, заснована на принципі забезпечення фундаментального права дітей на освіту та права на навчання за місцем проживання, у тому числі навчання дітей 3 особливими освітніми потребами, особливо дітей 3 особливостями психофізичного розвитку, в умовах загальноосвітнього навчального закладу» [5].

На нашу думку, це визначення повною мірою стосується навчальновиховного процесу таких дітей у дошкільних, професійно-технічних навчальних закладах, а також позашкільних освітніх установ. Міжнародні стандарти прав 
людини базуються на ідеї участі кожної людини в суспільному житті на засадах рівності та недискримінації. Розширення процесу інклюзивної освіти дітей 3 обмеженими можливостями в Україні є не лише відображенням часу, але також ще одним кроком до реалізації можливості забезпечити право дітей 3 особливими потребами на якісну освіту.

Однією з форм навчання дітей з особливими освітніми потребами $є$ нова, але визнана в багатьох країнах світу інклюзивна форма навчання, яка дає кожній дитині повне право відвідувати загальноосвітню школу за місцем проживання 3 усіма необхідними такій дитині умовами. В Україні модель інклюзивної освіти почала набувати значення переважно з ініціативи громадських організацій.

Для забезпечення рівного доступу до якісної освіти інклюзивним навчальним закладам необхідно адаптувати навчальні програми та навчальні плани, методи та стилі навчання, використовувати наявні ресурси для партнерства 3 громадою у відповідності до індивідуальних потреб дітей 3 особливими освітніми потребами. Інклюзивна освіта - це процес, у якому школа прагне задовольнити потреби всіх учнів шляхом внесення необхідних змін до навчальної програми та ресурсів, щоб забезпечити гарантування рівних можливостей [1].

Система закладів, що забезпечують спеціальну освіту в Україні, має вертикально-горизонтальну структуру. Вертикальна структура базується на вікових особливостях учнів та системі загальноосвітніх закладів різного рівня. Горизонтальна структура враховує психофізичний розвиток дитини.

Діти 3 порушеннями психофізичного розвитку можуть отримати спеціальний догляд у центрах раннього втручання, реабілітаційних центрах, психолого-медико-освітніх центрах та спеціальних дошкільних закладах.

До безсумнівних досягнень розвитку інклюзивної освіти в останні роки можна віднести: створення достатньої матеріальної бази в спеціальних навчальних закладах, забезпечення належних умов для надання спеціальної допомоги, організації професійної підготовки, навчання та відпочинку дітей 3 особливими потребами. У спеціальних закладах діти 3 вадами розвитку здобувають освіту, спрямовану на здобуття основ наук, удосконалення особистісних якостей, корекцію вад розвитку та подальшу соціалізацію. Корекційні заняття не тільки забезпечують корекцію порушень психофізичного розвитку, а й діють на особистість в цілому для досягнення позитивних результатів у іiі навчанні, вихованні та інтеграції в суспільство. Спеціальні заклади освіти в основному оснащені сучасними педагогічними та методичними матеріалами, розробленими відповідно до потреб сьогодення [6].

Навчання дітей в інклюзивних класах здійснюється відповідно до навчальних планів, програм, підручників i посібників, рекомендованих Міністерством освіти i науки України. Навчально-виховний процес в інклюзивних класах зосереджений на забезпеченні умов навчання та реабілітації, діти отримують особливу підтримку безпосередньо в школі. 
Щодо правового забезпечення інклюзивної освіти, то Законом України «Про освіту» гарантується право на освіту осіб з особливими освітніми потребами (ст. 19. Освіта осіб з особливими освітніми потребами, ст. 20. Інклюзивна освіта).

Важливим є відкриття в Україні інклюзивно-ресурсних центрів, створених для реалізації права дітей з особливими освітніми потребами віком від 2 до 18 років на дошкільну та загальну середню освіту, особливо в професійно-технічних та інших навчальних закладах, що $є$ важливим кроком для соціально орієнтованої держави у поступі до європейської інтеграції. Якщо у 2017 році не функціонував жоден 3 таких центрів, то у 2021 році їх нараховується в регіонах 638.

Це свідчить про позитивну динаміку інклюзивної освіти. У дошкільних відділеннях спеціальних закладів загальної середньої освіти 2019-2020 р. У 2012 році навчалося 2028 дітей дошкільного віку (у 2018 - 2019 роках - 2217 таких дітей). Загалом 32014 р. спостерігається позитивна тенденція збільшення кількості позашкільних навчальних закладів у системі освіти усіх типів надавачів на $1,1 \% 3$ незначними відхиленнями. За даними Державної науководослідної установи «Інститут аналітики освіти», за останні чотири роки в Україні кількість учнів, які навчаються в інклюзивних класах загальної середньої освіти, зросла в 4,5 рази (з 4180 учнів у 2016-2017 роках до 18643 учнів у 2019-2020 роках); кількість інклюзивних класів зросла майже в п’ять разів (з 2715 класів у 2016-2017 рр. до 13497 класів у 2019-2020 pp.), а асистентів у таких класах - майже у 7 разів - 2020 р. (рис.1, 2, 3, 4) [7].

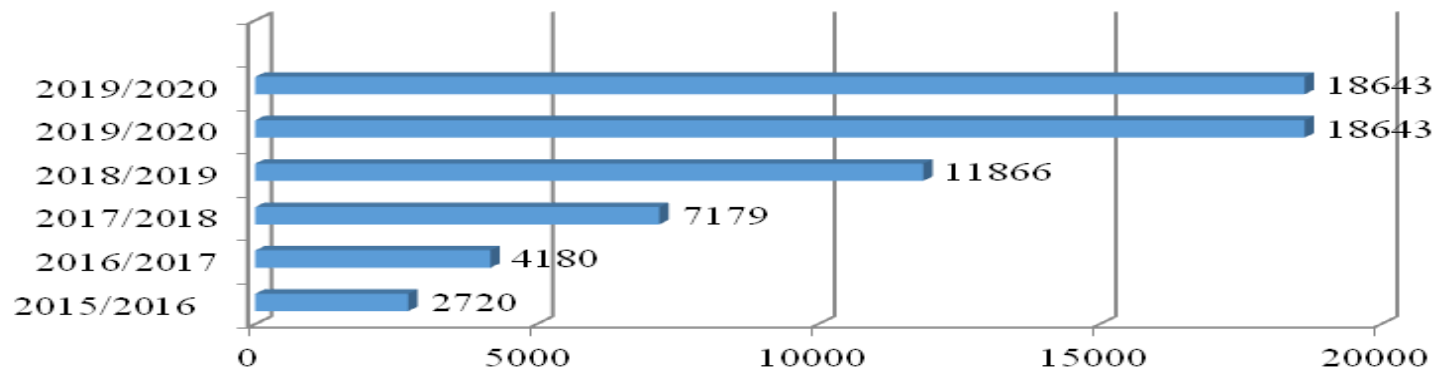

Рис. 1. Кількість учнів спеціальних закладів загальної середньої освіти Джерело: сформовано авторами за даними [7].

Як видно 3 рис. 1, за п'ять навчальних років кількість учнів 3 особливими освітніми потребами, які навчаються в інклюзивних класах закладів загальної середньої освіти, зросла в 6,9 рази (з 2720 учнів у 2015-2016 роках до 18643 учнів у 2019-2020 роках).

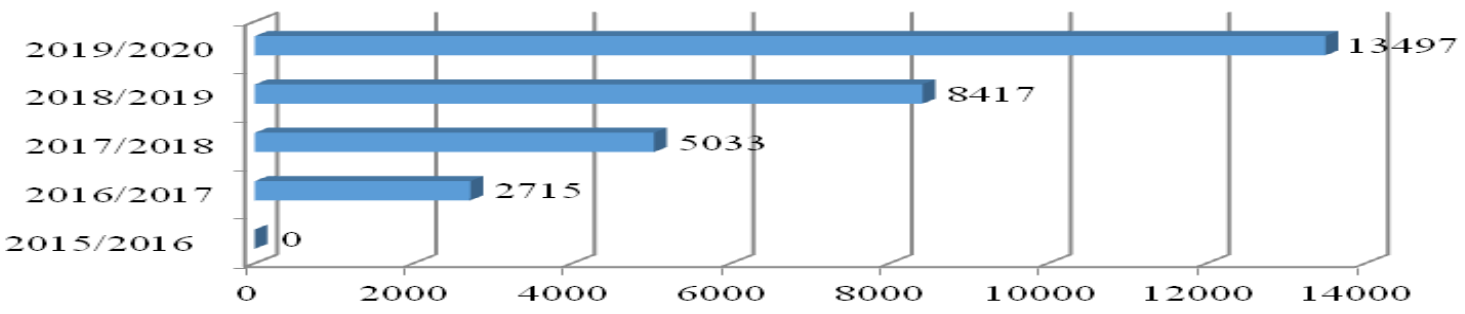

Рис. 2. Кількість інклюзивних класів у закладах загальної середньої освіти Джерело: сформовано авторами за даними [7] . 
Журнал«Герспективитаінновації наукиљ

(Серія«Гедагогіка», Серія«ГТихологія», Серія«Медицинв»

№2(7) 2022

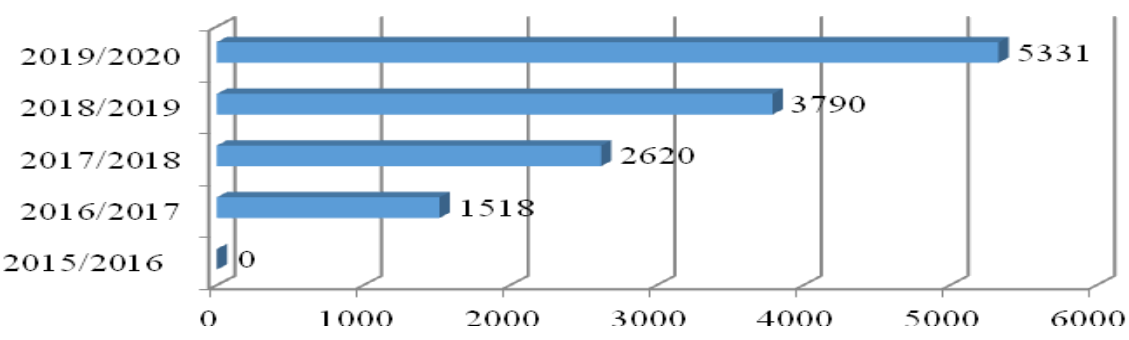

Рис. 3. Кількість закладів загальної середньої освіти, що мають інклюзивні класи

Джерело: сформовано авторами за даними [7].

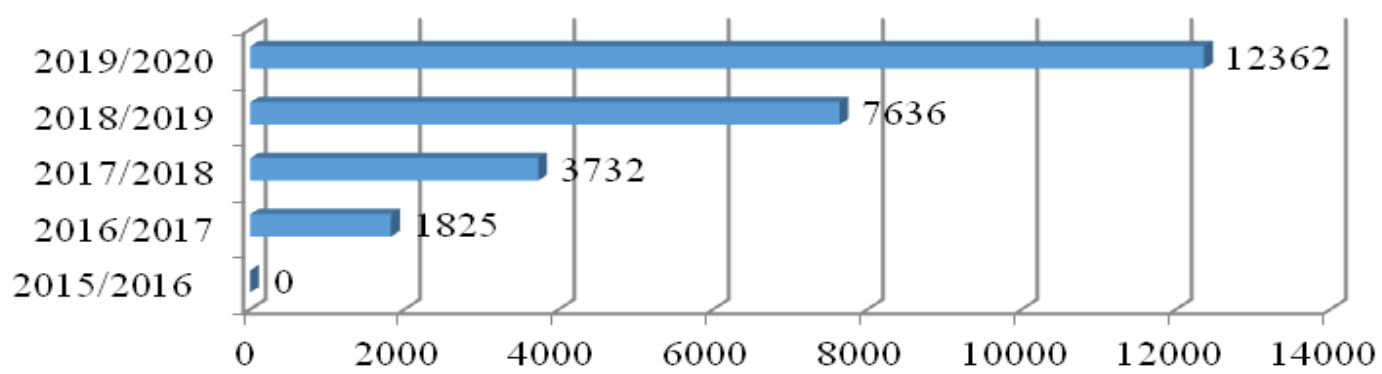

Puс. 4. Кількість асистентів вчителя, щцо працюють у закладах загальної середньої освіти

Джерело: сформовано авторами за даними [7].

Як видно 3 рис. 2-4, за чотири роки кількість інклюзивних класів зросла майже в п'ять разів (з 2715 класів у 2016-2017 рр. до 13497 класів у 2019-2020 рр.), а кількість шкіл з інклюзивними класами - у 3,5 рази (з 1518 шкіл у 2016-2017рр.) збільшилася до 5331 школи у 2019-2020 навчальному році). При цьому кількість асистентів за чотири роки зросла в 6,8 рази (з 1825 асистентів у 2016-2017 роках до 12362 асистентів у 2019-2020 роках) [7].

До основних досягнень сучасного інклюзивного освітнього середовища можна віднести суттєве збільшення кількості людей з особливими потребами, активно включених в суспільство, що отримують послуги 3 адаптації, соціалізації, навчання, виховання та розвитку на благо суспільства. Важливим аспектом інклюзивної освіти є забезпечення ефективності та якості навчання 3 використанням форм, методів і технологій, що враховують індивідуальні особливості людей з особливими потребами.

Інклюзивна освіта - це довгострокова стратегія від інтеграції в навчальний заклад до інтеграції в суспільство, що одночасно $є$ i процесом, і результатом. Інклюзивна освіта намагається далі розвивати свою філософію, теорію та методологію, розробляє нові підходи до навчального процесу, використовує специфічні корекційні засоби, удосконалює зміст, форми та технології навчання [8].

Проте, поряд із беззаперечними позитивними моментами, необхідно виділити суттєві недоліки сучасної системи спеціальної освіти, зокрема: 
- $\quad$ iï уніфікацію, що унеможливлює задоволення освітніх потреб усіх учнів із вадами розумового та фізичного розвитку до навчальних програм;

- $\quad$ ізоляцію великої кількості дітей з психофізичними відхиленнями в спеціальних школах-інтернатах, які є основними спеціальними навчальними закладами. Така ізоляція має багато негативних соціальних наслідків, зокрема: відчуження сім'ї від навчального процесу, соціальний інфантилізм учнів, обмеженість розвитку життєвих навичок тощо;

- недостатня соціально-практична спрямованість навчальновиховного процесу, наслідками якої є слабкий розвиток соціально-побутових навичок учнів, незадовільна орієнтація в системі соціальних норм і правил та відсутність навичок самостійного життя;

- недостатня індивідуалізація та особистісна спрямованість навчально-виховного процесу, що спричиняє труднощі в емоційноособистісному розвитку учнів, недостатне уявлення про їхні якості, здібності;

- низька ефективність корекційно-розвиваючих занять, що призводить до низької комунікативної компетентності, замкнутості;

- відсутність затвердженого психолого-просвітницького інструментарію для діагностики розладів, що ускладнює належне укомплектування спеціалізованих закладів та організацію відповідної підготовки;

- $\quad$ недостатнє науково-методично-педагогічне забезпечення навчальновиховного процесу дітей з тяжкими патологіями, атиповими порушеннями, що потребують додаткових освітніх, корекційно-реабілітаційних послуг [6].

У зв'язку з цим варто відзначити, що традиційний підхід у сучасній соціально-педагогічній практиці є однобічним, оскільки переважно спрямовує зусилля спеціалістів на реабілітацію дитини, а робота 3 її соціалізації або не ведеться взагалі, або використовується у якості опосередкованого впливу на цей процес. На сучасному етапі важливого значення набуває сприйняття осіб 3 особливими потребами як невід'ємних членів соціуму, що потребує спрямування соціально-педагогічної роботи не тільки на реабілітацію дітей, але й на підвищення рівня адаптації до життєвих умов, пов'язаних з вихованням дітей з особливими потребами.

Проблеми та суперечності розвитку інклюзії також стосуються: 1) недостатнього усвідомлення в суспільстві важливості розвитку інклюзї; 2) проблем освіти дітей 3 особливими потребами у сільській місцевості; 3) питання реального психолого-освітнього супроводу дітей 3 особливими потребами в загальноосвітніх навчальних закладах; 4) кадрових питань (у тому числі компетентності, бажання працювати з цією категорією); 5) недосконалості рівня підготовки вчителів, неприйняття інновацій у сфері інклюзивної освіти; 6) відсутності єдиної системи поступового впровадження інклюзивної освіти, починаючи 3 дошкільних закладів (безперервність цього процесу не гарантується); 7) браку ресурсів тощо. 
Журнал«Герспективитаінноваціїнаукиљ

(Серія«Гедагогіка», Серія«Гцихологія», Серія«Медицинв»

№2(7) 2022

Враховуючи найважливіші положення міжнародної та національної правової бази щодо інклюзивної освіти, оптимізувати навчання дітей 3 особливими потребами означає втілити основні принципи інклюзивної освіти:

- особисті здібності кожної людини не можуть визначити зниження його цінності як члена суспільства;

- 3 точки зору особистих досягнень, кожен має право відчувати, спілкуватися і бути почутим як рівноправний член суспільства;

- освітнє середовище (традиційне чи інклюзивне) створюється на основі активної взаємодії людей та спілкування між усіма суб'єктами (учнями, вчителями, батьками, спеціалістами з інклюзивної освіти тощо);

- інклюзивне освітнє середовище спонукає до розвитку всіх його учасників на основі толерантності, взаємодопомоги, співпереживання, розуміння, підтримки [9].

Таким чином, впровадження інклюзивної освіти $\epsilon$ складною, неоднозначною, багатошаровою проблемою, що пов'язує низку відносно самостійних науково-прикладних напрямів, потребує розгляду та подальшої розробки правових, психолого-педагогічних, програмних змістових, соціальнопсихологічних основ.

Висновки. Аналізуючи проблему впровадження інклюзивної освіти в Україні, ми стежимо за тривалим процесом реформи освіти загалом, зміни, яких вимагає інклюзія, вимагають не лише матеріального забезпечення, а й толерантності суспільства. Важко не помітити той факт, що в освітній галузі не контролюється динаміка залучення дітей з особливими освітніми потребами до навчального процесу. Робота 3 асистентами вчителів тільки розпочалася. Потребує 3'ясування питання про кількість дітей із особливими освітніми потребами у групі чи класі. Тому ефективність створення інклюзивного середовища потребує детального вивчення в кожному регіоні України. Проблема підготовки кадрового складу закладів загальної освіти $є$ надзвичайно гострою, оскільки рівень компетентності викладача конкретного закладу та асистента вчителя має певні відмінності та потребує детального аналізу, тому дослідження в майбутньому вищезазначених питань потребують особливої уваги.

\section{Лimepamypa:}

1. Кучай Т., Кучай О. Теоретичні основи інклюзивного навчання у закладах вищої освіти. Науковий вісник МНУ ім. В. О. Сухомлинського. 2019. № 2 (65). С. 162-164.

2. Цегельник Т. Педагогічні умови формування готовності майбутніх вихователів до професійної діяльності в інклюзивних групах закладів дошкільної освіти. Науковий вісник Льотної академії. 2020. Вип. 8. С. 138-144.

3. Чупахіна С. Упровадження інклюзивної освіти в Україні: реалії та перспективи. Освітній простір України. 2017. № 9. URL: http://nbuv.gov.ua/UJRN/opu_2017_9_35.

4. Москалюк О. Інклюзивна освіта в контексті проблем, суперечностей та перспектив. Науковий вісник Ужгородського університету. Серія «Педагогіка. Соціальна робота». 2017. № 1 (40) URL: https://dspace.uzhnu.edu.ua/jspui/bitstream.

5. Коробкіна О. Інклюзивна освіта в Україні: шляхи від теорії до практики. Харків. 2017. 57 с. 
6. Манжос Е. Інклюзивна освіта на сучасному етапі розвитку освітньої галузі. Педагогіка формування творчої особистості у вищій і загальноосвітній школах. 2019. № 62, T. 1. C. 59-62.

7. Крилошанська Л., Ундір В. Проблеми та перспективи розвитку інклюзивної освіти в Україні. Ефективність державного управління. 2021. Вип. 1 (66). Ч. 1. С. 70-80.

8. Лешер О., Деменина Л. Инклюзивное обучение студентов университета: комплекс научных подходов. URL: https://www.science-education.rU/pdf/2015/1/1190.pdf.

9. Мельничук I. Розвиток інклюзивної освіти в Україні. Науковий вісник Миколаївського національного університету імені В. О. Сухомлинського. 2020. № 1 (68). С. 165-170.

\section{References:}

1. Kuchaj, T., \& Kuchaj, O. (2019). Teoretychni osnovy inkljuzyvnogho navchannja u zakladakh vyshhoji osvity [Theoretical foundations of inclusive education in higher education]. Naukovyj visnyk MNU im. V. O. Sukhomlynsjkogho - Scientific Bulletin of MNU. VO Sukhomlinsky, 2 (65), 162-164 [in Ukrainian].

2. Cegheljnyk, T. (2020). Pedaghoghichni umovy formuvannja ghotovnosti majbutnikh vykhovateliv do profesijnoji dijaljnosti $\mathrm{v}$ inkljuzyvnykh ghrupakh zakladiv doshkiljnoji osvity [Pedagogical conditions for the formation of readiness of future educators for professional activities in inclusive groups of preschool education]. Naukovyj visnyk Ljotnoji akademiji - Scientific Bulletin of the Flight Academy, 8, 138-144 [in Ukrainian].

3. Chupakhina, S. (2017). Uprovadzhennja inkljuzyvnoji osvity v Ukrajini: realiji ta perspektyvy [Implementation of inclusive education in Ukraine: realities and prospects.]. Osvitnij prostir Ukrajiny - Educational space of Ukraine, 9. nbuv.gov.ua. Retrieved from: http://nbuv.gov.ua/UJRN/opu_2017_9_35 [in Ukrainian].

4. Moskaljuk, O. (2017). Inkljuzyvna osvita v konteksti problem, superechnostej ta perspektyv [Inclusive education in the context of problems, contradictions and prospects]. Naukovyj visnyk Uzhghorodsjkogho universytetu. Serija «Pedaghoghika. Socialjna robota» - Scientific Bulletin of Uzhgorod University. Series "Pedagogy. Social work", 1 (40). dspace.uzhnu.edu.ua. Retrieved from: https://dspace.uzhnu.edu.ua/jspui/bitstream. [in Ukrainian].

5. Korobkina, O. (2017). Inkljuzyvna osvita v Ukrajini: shljakhy vid teoriji do praktyky [Inclusive education in Ukraine: ways from theory to practice]. Kharkiv [in Ukrainian].

6. Manzhos, E. (2019). Inkljuzyvna osvita na suchasnomu etapi rozvytku osvitnjoji ghaluzi [Inclusive education at the present stage of development of the educational sector]. Pedaghoghika formuvannja tvorchoji osobystosti $u$ vyshhij $i$ zaghaljnoosvitnij shkolakh - Pedagogy of creative personality formation in higher and general education schools, 62 (1), 59-62 [in Ukrainian].

7. Kryloshansjka, L., \& Undir, V. (2021). Problemy ta perspektyvy rozvytku inkljuzyvnoji osvity v Ukrajini [Problems and prospects of inclusive education in Ukraine]. Efektyvnistj derzhavnogho upravlinnja - Efficiency of public administration, 1 (66.1), 70 -80 [in Ukrainian].

8. Lesher, O., \& Demenyna, L. Ynkljuzyvnoe obuchenye studentov unyversyteta: kompleks nauchnыkh podkhodov [Inclusive education of university students: a set of scientific approaches]. www.science-education.rU. Retrieved from: https://www.science-education.rU/pdf/2015/1/1190.pdf [in Ukrainian].

9. Meljnychuk, I. (2020). Rozvytok inkljuzyvnoji osvity v Ukrajini [Development of inclusive education in Ukraine]. Naukovyj visnyk Mykolajivsjkogho nacionaljnogho universytetu imeni $V$. $O$. Sukhomlynsjkogho - Scientific Bulletin of the Nikolaev National University named after VO Sukhomlinsky, 1 (68), 165-170 [in Ukrainian]. 